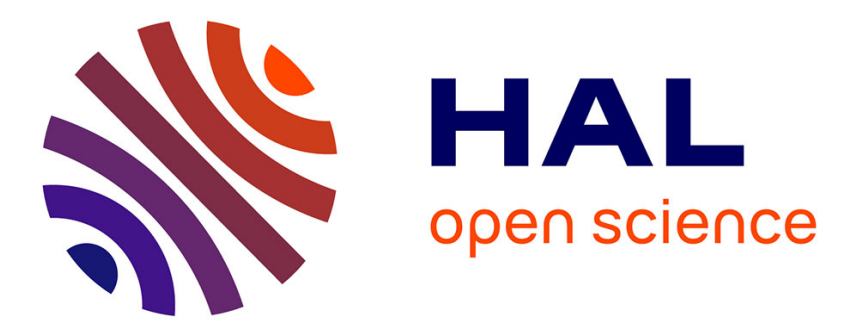

\title{
In-depth assessment of microbial communities in the full-scale vertical flow treatment wetlands fed with raw domestic wastewater
}

\author{
D.D. Silveira, P. Belli Filho, L.S. Philippi, M.E. Cantão, A. Foulquier, \\ Sandrine Bayle, T.P. Delforno, Pascal Molle
}

\section{To cite this version:}

D.D. Silveira, P. Belli Filho, L.S. Philippi, M.E. Cantão, A. Foulquier, et al.. In-depth assessment of microbial communities in the full-scale vertical flow treatment wetlands fed with raw domestic wastewater. Environmental Technology, 2021, 42 (20), pp.1-16. 10.1080/09593330.2020.1723709 . hal-02495544

\section{HAL Id: hal-02495544 \\ https://hal.mines-ales.fr/hal-02495544}

Submitted on 26 May 2021

HAL is a multi-disciplinary open access archive for the deposit and dissemination of scientific research documents, whether they are published or not. The documents may come from teaching and research institutions in France or abroad, or from public or private research centers.
L'archive ouverte pluridisciplinaire HAL, est destinée au dépôt et à la diffusion de documents scientifiques de niveau recherche, publiés ou non, émanant des établissements d'enseignement et de recherche français ou étrangers, des laboratoires publics ou privés. 


\title{
In-depth assessment of microbial communities in the full-scale vertical flow treatment wetlands fed with raw domestic wastewater
}

\author{
D.D. Silveira ${ }^{a}{ }^{a, b}$, P. Belli Filho ${ }^{a}$, L.S. Philippi ${ }^{a}$, M.E. Cantão ${ }^{c}$, A. Foulquier ${ }^{d}$, S. Bayle ${ }^{e}$, T.P. Delforno $\mathbb{1}^{f}$ and P. Molle ${ }^{b}$
}

aUFSC, Federal University of Santa Catarina, Florianópolis, Brazil; ' ${ }^{\mathrm{b} I N R A E}$, Villeurbanne, France; ' $E M B R A P A ~ S U I ́ N O S$ E AVES, Concórdia, Brazil; ${ }^{\mathrm{d} C N R S}$, LECA, Univ. Grenoble Alpes, Univ. Savoie Mont Blanc Grenoble, France; ${ }^{\mathrm{L}} \mathrm{GEI}$, IMT Mines Ales, Univ. Montpellier, Ales, France; ${ }^{\mathrm{f}}$ Microbial Resources Division, Research Center for Chemistry, Biology and Agriculture (CPQBA), Campinas University - UNICAMP, Campinas, Brazil

\section{ABSTRACT}

A multiphase study was proposed to examine microbial communities linked to the nitrogen cycle in the first stage of four full-scale French vertical flow treatment systems. To this end, denaturing gradient gel electrophoresis (DGGE) was performed for structural assessment and quantitative PCR ( $q P C R$ ) to enumerate the abundance of ammonia-oxidizing (AOB). 16S rRNA sequencing was used to assess the taxonomic profile followed by putative assessment of functional genes. The samples were collected under different conditions, such as operational time (presence/absence of sludge layer on the surface of the filters), season (winter and summer), sampling depth (0, 15 and $30 \mathrm{~cm}$ ) and operation cycle (rest and feed periods). A structural disparity was noted in the upper layers, whereas higher similarity at $30 \mathrm{~cm}$ was observed highlighting the effect of organic matter on bacterial diversity. The 7th rest day was highlighted by an apparent decline in the microbial community abundance. Additionally, qPCR indicated that the largest amount of $A O B$ was found at $30 \mathrm{~cm}$ depth and during the feeding period. From the taxonomic profile, Mycobacterium, Acinetobacter, Flavobacterium, and Nitrospira were the most abundant genre found in all systems. The functional prediction results showed predicted genes linked to the denitrification process. The results suggested that operating time and season were responsible for the pattern of the microbial community behavior. This study allowed us to further understand the bacterial dynamics and to advance the idea of design modifications made in the first stage of the classical French system to improve nitrogen removal are promising.

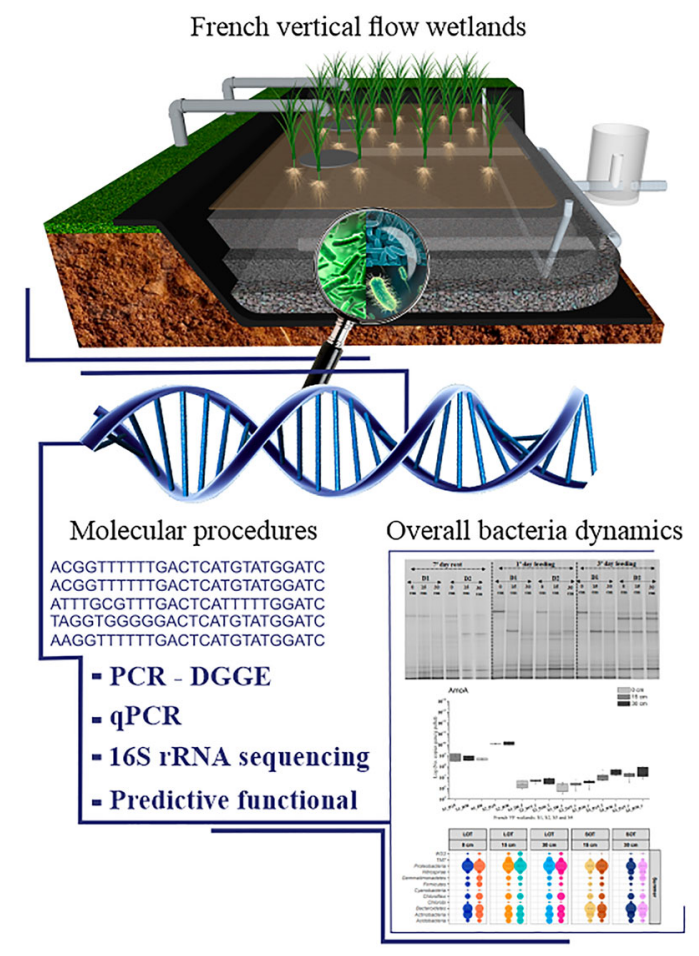

KEYWORDS

French VF wetland; Microbial community structure; Nitrifying bacteria; Taxonomic profile; Functional prediction

CONTACT D. D. Silveira danid_bioeng@yahoo.com.br E UFSC, Federal University of Santa Catarina, Campus Universitário, Trindade, 88040-900, Florianópolis, SC, Brazil; INRAE, UR REVERSAAL, 5 rue de la Doua, CS 20244F-69625 Villeurbanne, France

(6) Supplemental data for this article can be accessed https://doi.org/10.1080/09593330.2020.1723709 


\section{Introduction}

French vertical flow (VF) wetlands are biological systems where raw wastewater [1] percolates through a porous medium creating a sludge deposit layer on the top surface; hence, these systems treat sludge and wastewater in a single step (a specificity of French VF wetlands). In order to mitigate the clogging in the system, rest and feed periods are implemented, creating highly variable conditions of both water quality and oxygen content. Consequently, this might induce spatially (horizontally and with depth) [2] and temporal heterogeneity in the microbial population and, by extension, in microbial activity. This activity is the main factor responsible for the treatment performance and durability of the system. Furthermore, the French VF wetland has been adapted in a number of climates, such as cold $[3,4]$ and tropical climates [5-7], which would add another layer of variability to the microbiota distribution. Improving knowledge of microbial diversity and dynamics, together with the physicochemical results and their relationship with systems operation and efficiency, could help inform the system design and operation mode, thus improving the performance of French VF wetland. To date, there is little knowledge on the microbial dynamics in French VF wetlands opting instead to focus on global indicators (stability of nitrification, low rate of deposit accumulation, oxygen content within the filter material, etc.) [1] to evaluate performance.

From very early on, scientists have paved the way for microbial community assessment and provided evidence of the strong impact that the microorganisms have on pollutant degradation in treatment wetlands (TWs). Beginning in the 1980s, the literature started to report the use of activity and enumeration techniques and, from 2008, structural assessments and functional studies started to become more popular [8].

Weber [8] further points out that TW microbial community research has increased from 2013 to 2016, and microbial community structure was the most commonly used methodological type followed by activity, function, and enumeration, respectively.

More recently, great strides are being made in the field of microbial community assessment in TWs, with functional assessment methods being developed, better utilized, and is related directly to water treatment. The use of next-generation sequencing and biological computational tools have allowed cost-effective, largescale multiplexing analyses, which have transformed our understanding of the interactions between microbial communities and their corresponding niches $[8,9]$.

In this sense, several studies have benefited from these techniques to evaluate the microbiota of TWs
[10-21]. Some authors [22-24] have also reported on the dynamics and heterogeneity of TWs and emphasize that changes in environmental conditions and other factors such as layer depth and operational time $[25,26]$, wastewater quality characteristics [27] and flow [28], can result in variations in composition, bacterial structure and influence the quality of the final effluent.

All of these studies have provided valuable information on the microbial community's behavior and identification. However, since microbiota are known to be heterogeneous, temporally dynamic, and structurally and functionally diverse, especially in wetland systems that possess a vast array design modifications, additional efforts are required to gain a solid understanding of microbial community dynamics, diversity, and potential functional under different operational conditions [8]. Thus, further studies should be performed, especially in full-scale systems, which operate over longer periods with well-defined parameters and an established bacterial community. To our knowledge, this study is the first to address this issue to improve our understanding of the microbial community in classical French VF wetland at a full-scale. Due to the importance of improving nitrogen performances of the first stage of the French system, this study is mainly focused on the bacteria involved in the nitrogen cycle in order to better inform design and operation modes in the future. In this framework, this paper proposes a multiphase study aimed to assess microbial community through identification of the dominant genes, highlighting the bacteria linked to the nitrogen cycle, and understand their structural and potential function dynamics spatially and temporally on the first stage of French VF treatment systems.

\section{Materials and methods}

\subsection{French vertical flow wetlands - description of the systems and physicochemical analyses}

In this study, the first stage of four classical French vertical flow wetlands (denoted as S1 through S4) treating domestic wastewater at a full-scale was used for the analysis of microbiota from the filters (Figure 1). The selected French VF wetlands are located in different cities (see map in Figure 1a) and were all designed according to the design standards for the classical twostage French vertical flow wetland design (Figure 1b) $[1,29,30]$.

The classical French systems are comprised of two stages, and each stage contains alternately operated cells. More specifically, the first stage is divided into three parallel cells (total of $1.2 \mathrm{~m}^{2} / \mathrm{PE}$ ) where the sludge treatment, partial removal of organic matter 


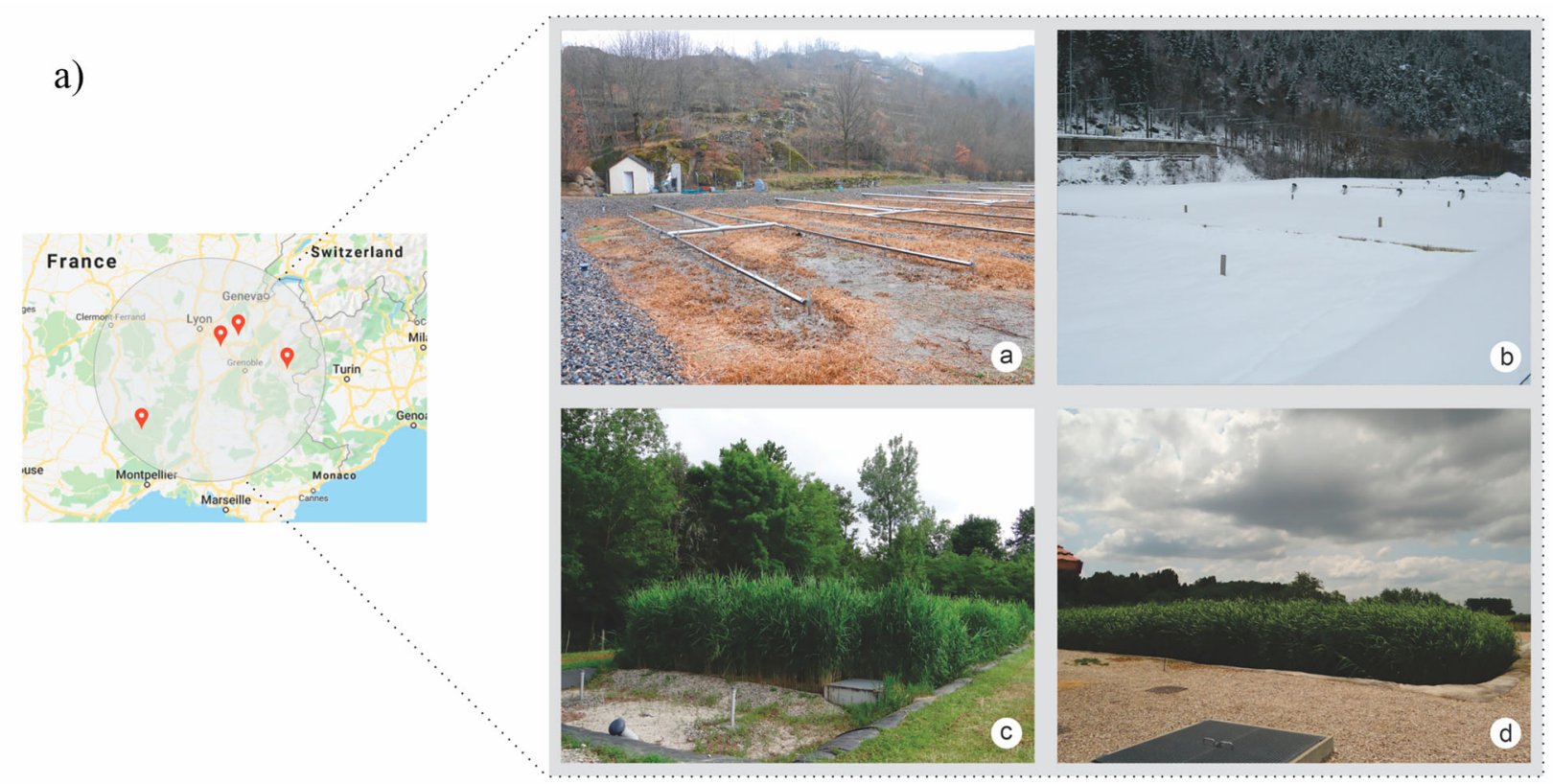

b)

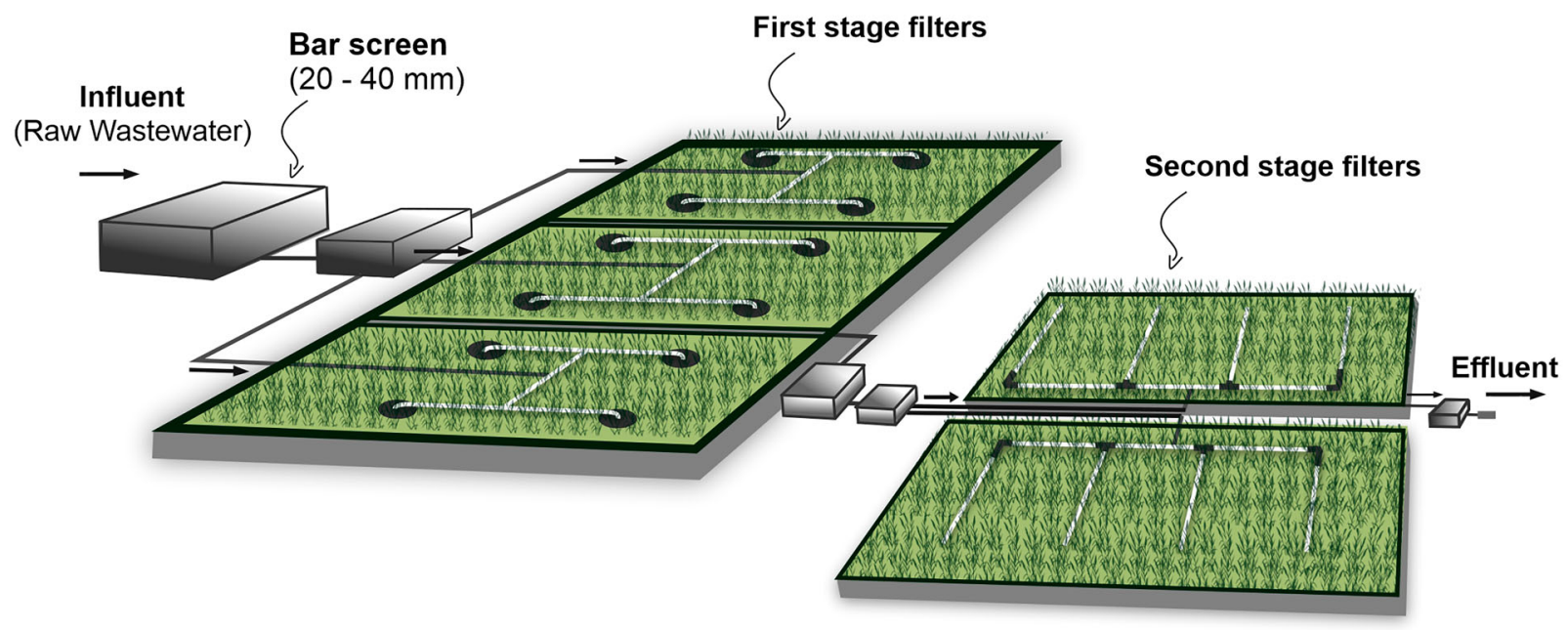

Figure 1. First stage French VF wetlands on a full-scale. a) Location map and evaluated systems: a) S1 (1800 m²); b) S2 (1204 m²); c) S3 $\left(240 \mathrm{~m}^{2}\right)$; d) S4 $\left(600 \mathrm{~m}^{2}\right)$. b) Schematic of the classical French VF design highlighting the first stage [adapted from 30].

and nitrification occur. Raw wastewater initially passes through a simple screen of $20-40 \mathrm{~mm}$ mesh before being fed into the system. The filters are fed for 3.5 days and then rest for 7 days. The first stage is composed of three layers: the upper layer (the main layer responsible for ensuring aerobic conditions) composed of $2 /$ $6 \mathrm{~mm}$ gravel; a transition or intermediate layer (5/ $15 \mathrm{~mm}$ gravel) and a drainage layer, which consists of coarse gravel $(20 / 60 \mathrm{~mm})$ at the bottom of the bed. Note that only one of three parallel cells and the upper layer was evaluated in this study and all filters had the same filter material $(2 / 6 \mathrm{~mm})$.

Average influent pollutant concentrations and removal efficiencies for the first stage of the VF wetlands are presented in Table 1. Also, the average hydraulic and organic loads on the filter during operation are included $(\mathrm{m} / \mathrm{d})$. All removal rates refer to first stage treatment performances [1], and systems can be considered as similar in terms of performances regarding the variation of flow and climatic conditions. 
Table 1. Average influent pollutant concentrations and removal efficiencies.

\begin{tabular}{|c|c|c|c|c|c|c|c|c|}
\hline & \multicolumn{2}{|r|}{ S1 } & \multicolumn{2}{|r|}{$\mathrm{S} 2$} & \multicolumn{2}{|r|}{ S3 } & \multicolumn{2}{|r|}{ S4 } \\
\hline & Value & Removal rate (\%) & Value & Removal rate (\%) & Value & Removal rate $(\%)$ & Value & Removal rate (\%) \\
\hline Organic (COD) load $\left(\mathrm{g} / \mathrm{m}^{2} / \mathrm{d}\right)$ & 181 & - & 162 & - & 226 & - & 128 & - \\
\hline Hydraulic load $(\mathrm{m} / \mathrm{d})$ & 0.28 & - & 0.30 & - & 0.46 & - & 0.21 & - \\
\hline $\mathrm{BOD}_{5}(\mathrm{mg} / \mathrm{l})$ & 304 & 87 & 200 & 78 & 197 & 76 & 252 & 82 \\
\hline $\operatorname{COD}(\mathrm{mg} / \mathrm{l})$ & 649 & 83 & 541 & 74 & 493 & 68 & 611 & 78 \\
\hline TSS (mg/l) & 275 & 89 & 281 & 85 & 193 & 75 & 238 & 81 \\
\hline TKN (mg/l) & 65 & 59 & 73 & 45 & 78.2 & 55 & 64 & 53 \\
\hline Temperature $\left({ }^{\circ} \mathrm{C}\right)$ & $6^{\circ} \mathrm{C}$ & - & $3^{\circ} \mathrm{C}$ & - & $22^{\circ} \mathrm{C}$ & - & $24^{\circ} \mathrm{C}$ & - \\
\hline
\end{tabular}

\subsection{Molecular analyses of the samples}

\subsubsection{Sampling characteristics}

The four full-scale systems evaluated in this study had been under long-term operation (at least two years), and therefore, the microbial communities were considered stable.

The objective was to select French VF wetlands with similar designs, but different operational times (short operation time - SOT, operating approximately for two years, and long operation time - LOT, i.e. with different deposit layer heights of organic matter) and sample them across two seasons, winter and summer. Two of the systems (one SOT and one LOT), which are well described [3], were selected in a mountainous area (S1 and S2), whereas the other two wetlands were located in plains (S3 and S4).

Additionally, different sampling points were selected to conduct the temporal and spatial evaluation including different depths $(0,15$ and $30 \mathrm{~cm})$, distance from a feeding point (1 and $2 \mathrm{~m}$ ). For S3 and S4 systems, additional sampling was conducted to examine the influence of the operation cycle (feeding/rest period) on the microbial communities. Table 2 summarizes the conditions and sampling strategy of each site.

We used a stainless-steel core drill (SDEC France - a soil sampler sold commercially) that was $100 \mathrm{~cm}$ in length and $5 \mathrm{~cm}$ in diameter to sample the filter material.
Two individual plexiglass tubes of $30 \mathrm{~cm}$ were cored from each system, at 1 (d1) $\mathrm{m}$ and 2 (d2) $\mathrm{m}$ from the feeding point respectively, to extract the filter material. This core was then sampled at $0 \mathrm{~cm}$ (deposit layer), 15, and $30 \mathrm{~cm}$ depths. However, in the SOT systems where no sludge was present, collection occurred only at depths of 15 and $30 \mathrm{~cm}$. A minimum of $60 \mathrm{~g}$ was collected at each sample point.

Ultimately, regarding the molecular techniques used in this study, denaturing gradient gel electrophoresis (DGGE) analysis was chosen to visualize the bacterial community structure. Owing to the focus on the nitrogen cycle in the first stage, the DGGE analysis was centered on the ammonia-oxidizing bacteria (AOB), which are responsible for nitrification, to verify the bacterial temporal and spatial profiles. In total, 70 samples (4 samples for S1, 6 samples for S2, 36 samples for S3 and 24 samples for 54 ) were characterized by DGGE analysis.

After the analysis of the results from DGGE, for the taxonomic analysis and functional potential of the microbiota, only samples from $\mathrm{d} 1$ were selected and a sample pool was considered for feeding and rest periods. Following this, a total of 15 samples were amplified, 2 for S1, 3 for S2, 6 for S3 and, 4 for S4. Table 3 details the codes for the sampling points for these analyses and a sampling schematic plan is shown in Supplementary Figure 1

Table 2. The conditions and sampling strategy of each system evaluated.

\begin{tabular}{|c|c|c|c|c|}
\hline \multirow{2}{*}{$\begin{array}{l}\text { Variables } \\
\text { Systems and location }\end{array}$} & \multicolumn{4}{|c|}{ Description } \\
\hline & $\begin{array}{l}\text { S1 (Pont de Montvert) } \\
\text { Mountain }\end{array}$ & $\begin{array}{l}\text { S2 (Orelle) } \\
\text { Mountain }\end{array}$ & $\begin{array}{l}\text { S3 (Evieu) } \\
\text { Plain }\end{array}$ & $\begin{array}{l}\text { S4 (Culin) } \\
\text { Plain }\end{array}$ \\
\hline Operational time & SOT & LOT & LOT & SOT \\
\hline \multicolumn{5}{|l|}{$\begin{array}{l}\text { - Young: short operation time (SOT) } \\
\text { - Old: long operation time (LOT) }\end{array}$} \\
\hline Deposit height $(\mathrm{cm})$ & 0 & $>10$ & $>10$ & 0 \\
\hline Measurement season & Winter & Winter & Summer & Summer \\
\hline Sampling distance from a feeding point & 1 and 2 meters & & & \\
\hline Sampling depth from the surface of each distance $(\mathrm{cm})^{*}$ & $15-30$ & $0-15-30$ & $0-15-30$ & $15-30$ \\
\hline Sampling operation cycle & - & - & Feeding/rest period & Feeding/rest period \\
\hline
\end{tabular}

* 0 (deposit layer), first $15 \mathrm{~cm}$ to $30 \mathrm{~cm}$ depth of the first layer of gravel $(2 / 6 \mathrm{~mm})$ 
Table 3. Information on the sampling points used to collect and display data.

\begin{tabular}{|c|c|c|}
\hline French VF wetlands & Code & Information \\
\hline S1 & $\begin{array}{l}\text { S1_D15 } \\
\text { S1_D30 }\end{array}$ & $\begin{array}{l}\text { S1 }=\text { System } 1 \\
\text { D15 }=15 \mathrm{~cm} \text { depth } \\
\text { D } 30=30 \mathrm{~cm} \text { depth }\end{array}$ \\
\hline S2 & $\begin{array}{l}\text { S2_D0 } \\
\text { S2_D15 } \\
\text { S2_D30 }\end{array}$ & $\begin{array}{l}\mathrm{S} 2=\text { System } 2 \\
\mathrm{D} 0=0 \mathrm{~cm}-\text { deposit layer } \\
\text { D15 }=15 \mathrm{~cm} \text { depth } \\
\text { D30 }=30 \mathrm{~cm} \text { depth }\end{array}$ \\
\hline S3 & $\begin{array}{l}\text { S3_D0_f } \\
\text { S3_D15_f } \\
\text { S3_D30_f } \\
\text { S3_D0_r } \\
\text { S3_D15_r } \\
\text { S3_D30_r }\end{array}$ & $\begin{array}{l}\text { S3 }=\text { System } 3 \\
\text { D0 }=0 \mathrm{~cm}-\text { deposit layer } \\
\text { D15 }=15 \mathrm{~cm} \text { depth } \\
\text { D30 }=30 \mathrm{~cm} \text { depth } \\
f=\text { feeding period } \\
r=\text { rest period }\end{array}$ \\
\hline S4 & $\begin{array}{l}\text { S4_D15_f } \\
\text { S4_D30_f } \\
\text { S4_D15_r } \\
\text { S4_D30_r }\end{array}$ & $\begin{array}{l}\mathrm{S} 4=\text { System } 4 \\
\text { D15 }=15 \mathrm{~cm} \text { depth } \\
\text { D30 }=15 \mathrm{~cm} \text { depth } \\
f=\text { feeding period } \\
r=\text { rest period }\end{array}$ \\
\hline For all systems & d1 & $\begin{array}{l}\mathrm{d} 1=\text { distance from the feeding } \\
\text { point }-1 \mathrm{~m}\end{array}$ \\
\hline
\end{tabular}

\subsubsection{DNA extraction, $P C R$ and profiles of the} amplifications by DGGE

Genomic DNA was extracted from pellets of concentrated effluent using the Power Soil ${ }^{T m}$ DNA Isolation Kit (Mobio ${ }^{\mathrm{TM}}$, laboratories, Inc., Carlsbad. CA. EUA) according to the manufacturer's protocol. Then, the DNA was amplified by polymerase chain reaction (PCR) using an ammonia-oxidizing community (AOB)specific primer set: CTO $189 f$ (5'-GGAGRAAAGCAGGGGATCG-3'), CTO $189 f$ GC (5'-GGAGGAAAGTAGGGGATCG-3') and the reverse primer CTO 654R (5 '-CTAGCYTTGTAGTTICAAACGC-3'). The size of the amplified region was $465 \mathrm{bp}$ [31], corresponding to the V3-V4 region of the 16S rRNA gene using the following procedure: activation (hot start) at $95^{\circ} \mathrm{C}$ for $15 \mathrm{~min}, 35$ cycles of three steps (denaturation at $94^{\circ}$ $\mathrm{C}$ for $30 \mathrm{~s}$, hybridization at $57^{\circ} \mathrm{C}$ for $30 \mathrm{~s}$, and extension at $72^{\circ} \mathrm{C}$ for $1 \mathrm{~min}$ ). Followed by a final extension at $72^{\circ}$ $\mathrm{C}$ for $5 \mathrm{~min}$. The PCR mixtures contained $2.5 \mu \mathrm{l}$ DNA, $250 \mu \mathrm{M}$ dNTP, $1.5 \mathrm{mM} \mathrm{MgCl} 2,0.32 \mu \mathrm{M}$ CTO 189F, $0.16 \mu \mathrm{M}$ CTO 189F, $0.48 \mu \mathrm{M}$ CTO 654R, $0.625 \mathrm{U}$ Taq polymerase and $1 \mathrm{X}$ buffer.

After PCR, the standardized samples were placed on an acrylamide/bisacrylamide gel at a concentration of $6 \%(\mathrm{v} / \mathrm{v})$ with denaturing gradients of urea and formamide at concentrations of $15 \%$ and $55 \%$ for the DGGE gels. The run characteristics were as follows: $200 \mathrm{~V}$ for $6 \mathrm{~h}$ at $60^{\circ} \mathrm{C}$. The profiles of the amplifications were analyzed using the program GelCompar II version 6.5 (BioSystematica ${ }^{\mathrm{TM}}$, Wales. UK) with hierarchical clustering using the Jaccard index and the UPGMA clustering model.

\subsubsection{Quantitative $P C R$}

To quantify the $A O B$ the primers amoA if (GGGGTITCTACTGGTGGT) and amoA $2 r$ (CCCCTCKG SAAAGCCTTCTTC) [32] were used and total bacteria 16S rRNA was assessed using the primers 1055f (ATGG CTGTCGTCAGCT) and 1392r (ACGGGCGGTGTGTAC) [33,34]. Quantitative PCR (qPCR) was carried out in duplicate with an $\mathrm{IQ}^{\mathrm{TM}}$ (Bio-Rad, CA. EUA) and $2 \mu \mathrm{l}$ DNA $(5 \mathrm{ng} / \mu \mathrm{l})$ in a CFX96 Real-Time System C1000 Thermal Cycler using the following run conditions for total bacteria: $95^{\circ} \mathrm{C}$ for $3 \mathrm{~min} ; 40$ cycles of three steps, denaturation at $95^{\circ} \mathrm{C}$ for $30 \mathrm{~s}$, hybridization at $60^{\circ} \mathrm{C}$ for $30 \mathrm{~s}$, and extension at $75^{\circ} \mathrm{C}$ for $30 \mathrm{~s}$; and a final step at $65^{\circ} \mathrm{C}-95^{\circ} \mathrm{C}$ for $10 \mathrm{~min}$. For $\mathrm{AOB}$, the run conditions were $95^{\circ} \mathrm{C}$ for $3 \mathrm{~min} ; 40$ cycles of three steps, denaturation at $95^{\circ} \mathrm{C}$ for $30 \mathrm{~s}$, hybridization at $56^{\circ} \mathrm{C}$ for $30 \mathrm{~s}$, and extension at $75^{\circ} \mathrm{C}$ for $45 \mathrm{~s}$; and a final step at $65^{\circ} \mathrm{C}-$ $95^{\circ} \mathrm{C}$ for $10 \mathrm{~min}$. The data were automatically recorded on a qPCR Bio-RadTM CFX Manager Quantity One device. Standard curves were obtained using a serial dilution of synthetic plasmids containing the amoA gene (the gene that carries out the first nitrification step, $\mathrm{NH}_{4}^{+} \rightarrow \mathrm{NO}_{2}^{-}$) or rrs gene (the gene coding for $16 \mathrm{~S}$ rDNA, which allows the assessment of the total bacterial community) and ranged from $1 \mathrm{E}^{+07}$ to $1 \mathrm{E}^{+02}$ gene copies/ $\mu$ l. The qPCR efficiency ranged between 85 and $110 \%$.

\subsubsection{High-throughput sequencing and statistical analyses}

For High-throughput 16S rRNA sequencing analysis, all $16 \mathrm{~S}$ rRNA reads were analyzed using sequencing of the V3-V4 region on the extracted DNA. The universal primers 341F 5'-CCTACGGGRSGCAGCAG-3' [35] and 806R 5'-GGACTACHVGGGTWTCTAAT-3' [36] were utilized since this pair has good taxonomic coverage in Bacteria and Archaea [37]. Purified products were sent to the company Neoprospecta Microbiome Technologies, Inc. (Florianópolis, Brazil) for sequencing using the Miseq platform (Miseq ${ }^{\mathrm{TM}}$, Illumina Inc., USA). The data was processed using mothur, version 1.33.3 [38], following the MiSeq standard operating procedure (SOP) (http:// www.mothur.org/wiki/MiSeq_SOP) [39]. Sequences were clustered into operational taxonomic units (OTUs) at 0.03 (97\% similarity) and classified using SILVA Database release 119 [40].

The count table and metadata from taxonomic annotation from mothur was imported as phyloseq object., In the R Statistical environment, a complete workflow was developed for data exploration, statistical analyses, and graphics. Alpha diversity (observed richness, Chao1, 
and Shannon), beta diversity (Principal Coordinates Analysis - P(OA) and rare curve function were obtained after the normalization process.

Phylogenetic Investigation of Communities by Reconstruction of Unobserved States (PICRUSt) (version 1) was used to predict the metabolic dynamics of the communities [41] from the 16S rRNA gene using the recommendation obtained in the online protocol (http://picrust. github.io/picrust/). For that, OTUs were closed-reference picked against the May 2013 Greengenes database using QIIME (version 1.9.1) with 0.97 similarities [42]. The functional predictions were assigned to KEGG Ortholog, and the data were explored using KEGG modules (nitrogen conversion).

Sequencing data yielded in this study has been deposited in the European Nucleotide Archive under the accession number PRJEB31770.

\section{Results and discussion}

\subsection{Bacterial biofilm detachment}

The detachment technique of bacterial communities from biofilms is as critical as the techniques used for the detection of bacteria. It must be carefully performed so that a maximum number of bacteria can be detected to make the sample as representative as possible. Thus, to evaluate the best bacterial biofilm detachment method, several procedures were tested in this study. The method chosen included two steps: bacterial biofilm detachment and DNA extraction. The procedure that obtained the highest DNA concentration ( $\mathrm{ng} / \mu \mathrm{l}$ ) (variation from $2 \%$ to $12 \%$ more DNA concentration) and that had the highest degree of replicability was then chosen as the method to be applied in this study. The procedure is as follows: approximately $60 \mathrm{~g}$ of the collected material was placed in a circular vessel, followed by the addition of ultrapure autoclaved water, and finally, the samples were placed on a shaking platform for $3 \mathrm{~h}$ at $200 \mathrm{rpm}$. After that, the liquid was transferred to individual centrifuge tubes by filtering with the aid of a $2 \mathrm{~mm}$ sieve to remove only large particles. Subsequently, the samples were centrifuged for $10 \mathrm{~min}$ at 12 $000 \mathrm{rpm}$. Once the supernatant had been removed, the pellet weight was noted, and the biomass was stored at $-20^{\circ} \mathrm{C}$ until the moment of use.

\subsection{Microbial community assessment}

\subsubsection{Bacterial community structure}

As a result of the structural assessment, in system 1 (S1), the statistical values determined by UPGMA indicated a high similarity among different depths and distances

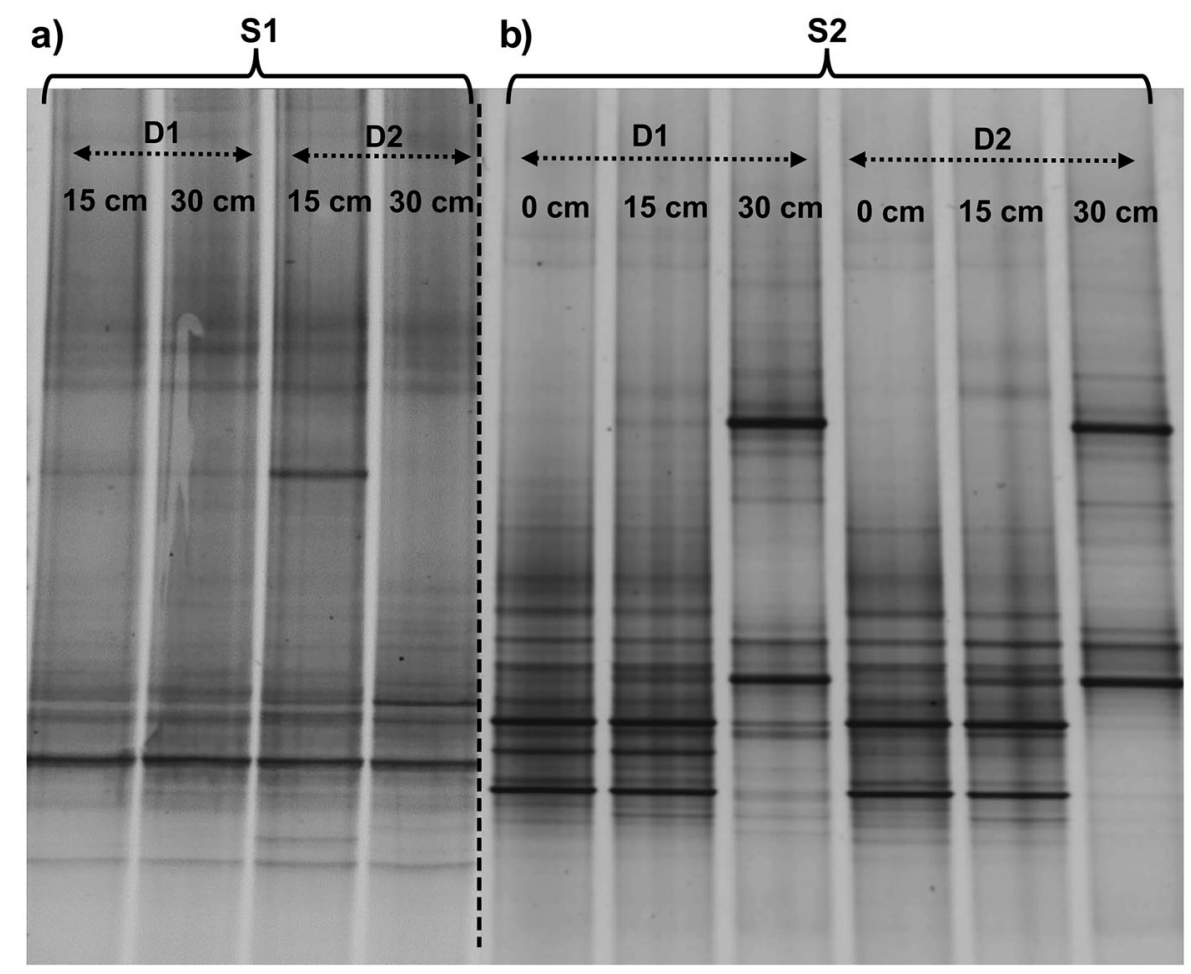

Figure 2. DGGE gel banding temporal and spatial profiles of nitrifying (AOB) bacterial communities in systems (a) S1 and (b) S2. d1 = 1 $\mathrm{m}$ from the feeding point; $\mathrm{d} 2=2 \mathrm{~m}$ from the feeding point; 0,15 and $30 \mathrm{~cm}$ depth. Each black line represents a band that corresponds to a group of $A O B$. 
$(\approx 80 \%)$ (Figure 2$)$. This homogeneity may be linked to the fact that $\mathrm{S} 1$ is a short operation time (SOT) system and because there was a good distribution of the effluent in the area above the filter during feeding. As for the S2, the differences between the depths - high disparity in the upper layers and greater similarity (85\%) in $30 \mathrm{~cm}$ was observed. This result highlighted the effect of organic matter deposition on bacterial diversity. This is understandable since organic deposition offers good conditions for the development of bacteria due to the presence of food supply and humidity [2]. This observation is consistent with the fact that-provided there is an adequate oxygen concentration-aging of the system is beneficial for treatment efficiency. Moreover, the presence of $A O B$ at $30 \mathrm{~cm}$ may indicate that aerobic conditions are prevalent throughout the filter even under various conditions, such as low temperatures and the presence of snow.

For S3 system, a temporal evolution was observed through the feeding and rest periods (Figure 3). We uniformly noted a reduction in diversity and intensity throughout the rest period and an increase during the feeding period. The results obtained by UPGMA statistical analysis confirmed $-80 \%$ similarity for 1 st and 2 nd rest days, between the 15 and $30 \mathrm{~cm}$ depths and between distances. On the 4th rest day, we visually observed a lower bacterial community intensity, which was $59 \%$ similar to the 1 st rest day, indicating a change in the bacterial profile. The 7th rest day showed an apparent decline in the number and intensity of bands compared to the first rest days. Thus, it can be concluded that this rest time (seven days) would be enough to avoid an excessive decline in the AOB community, thus optimizing the efficiency of the treatment.

The feeding period showed similarities above $75 \%$, and its distances (d1 and $\mathrm{d} 2$ ) presented a higher similarity above $80 \%$. This result may indicate a good homogenization of the wastewater distribution in the system (two feeding points for a $35 \mathrm{~m}^{2}$ area with a $1 \mathrm{~m}^{3} / \mathrm{h} / \mathrm{m}^{2}$ feed flow) as the filters had good operational behavior. Among the depths analyzed, the bacterial community was noted to be more similar (above 90\%) at 15 and $30 \mathrm{~cm}$.

The molecular fingerprint of the $\mathrm{S} 4$ system is shown in Figure 4. In general, it appears that in the SOT system, a lower diversity of $A O B$ may be found. This result could be related to the fact that it is a young system.

\subsubsection{Quantification of ammonia-oxidizing bacteria and total bacteria}

To quantify the functional potential, qPCR was performed based on the number of copies of amoA $/ \mathrm{g}$ pellet of $A O B$ and the number of copies of $\mathrm{rrs} / \mathrm{g}$ pellet. The gene concentrations for all systems are shown in Figure 5.

Regarding the S1 and S2 systems, it was possible to observe that at S1 (which does not contain organic deposits) the largest amount of $A O B$ was found at the $15 \mathrm{~cm}$ depth $(\log 1.00 \mathrm{E}+09)$; however, at S2 (which has organic deposits), a greater amount was found at $30 \mathrm{~cm} \quad(\log 1.00 \mathrm{E}+11)$. This result corroborated the results of DGGE gels, which showed that the deposit layer, snow and the presence of an aeration drain (promoting aeration from the bottom) seem to influence the spatial structure and functional potential of the bacterial community, favoring nitrifying bacteria in the layers below the surface. For the total bacteria, the number of gene copies/g pellet showed a little variation (values were on the order of $\log 1.00 \mathrm{E}+11$ ) for $\mathrm{S} 2$.

The qPCR results for system S3, in general, showed that the amount of $A O B$ and total bacteria increased with depth $(\log 1.00 \mathrm{E}+06$ and $\log 1.00 \mathrm{E}+07$,

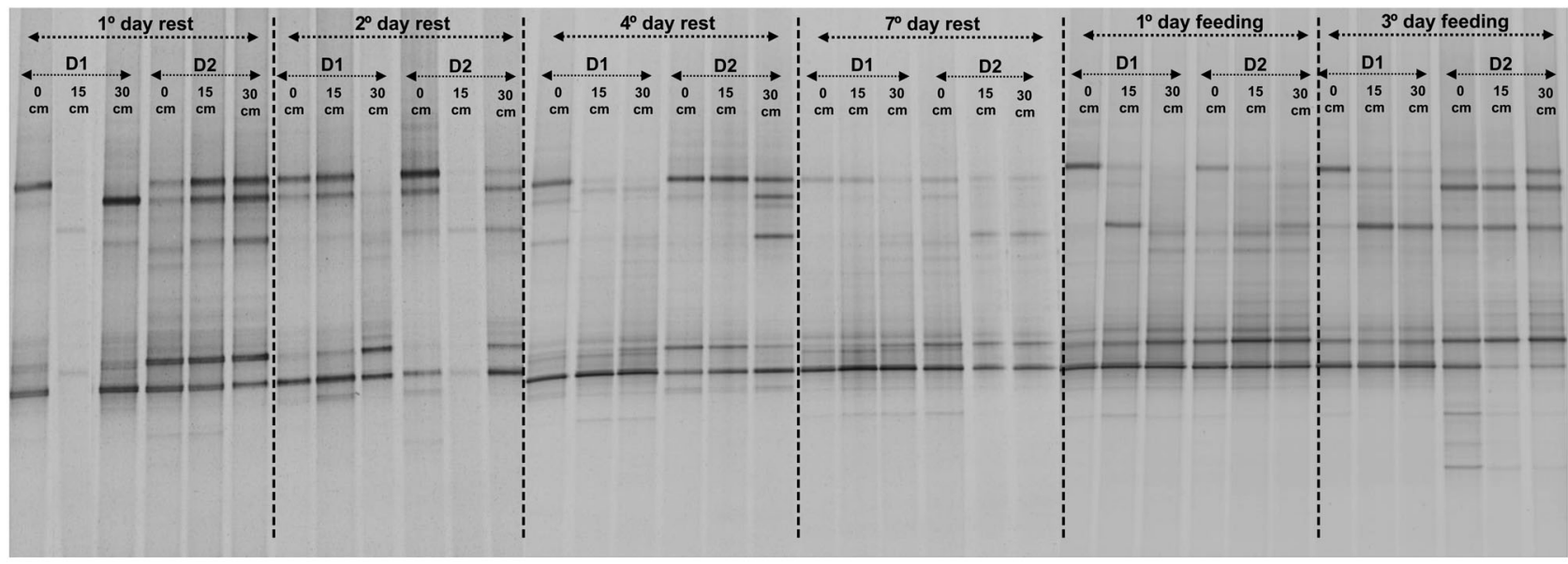

Figure 3. Temporal and spatial DGGE profiles of a nitrifying (AOB) bacterial community in S3. $\mathrm{d} 1=1 \mathrm{~m}$ from the feeding point; $\mathrm{d} 2=2 \mathrm{~m}$ from the feeding point; 0,15 and $30 \mathrm{~cm}$ depth. 


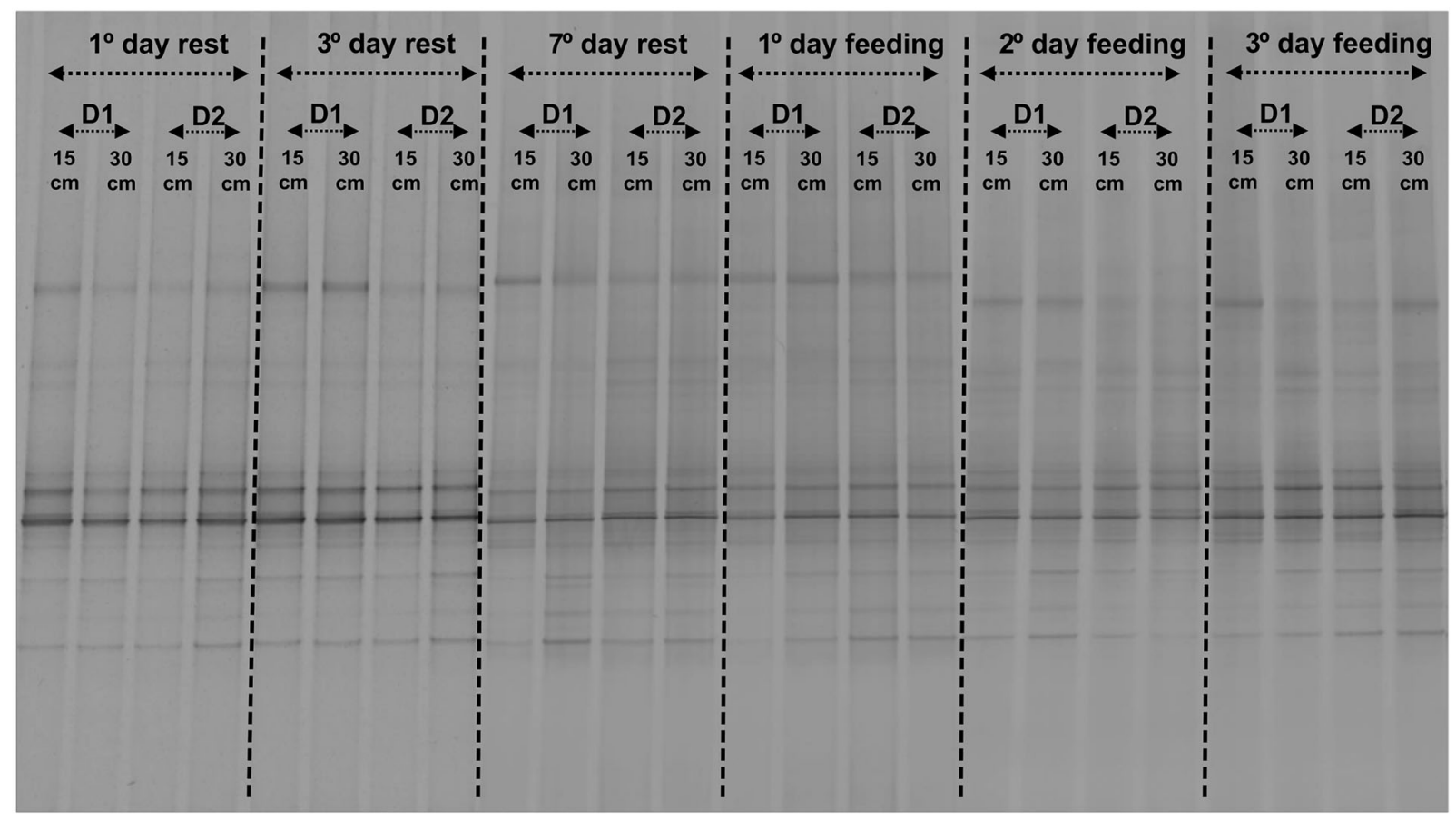

Figure 4. DGGE gel banding showing the temporal and spatial profiles of a nitrifying bacterial community in $\mathrm{S} 4$. $\mathrm{d} 1=1 \mathrm{~m}$ from the feeding point; $\mathrm{d} 2=2 \mathrm{~m}$ from the feeding point; 0,15 and $30 \mathrm{~cm}$ depth.

respectively, at $30 \mathrm{~cm}$ ). In this way, the influence of organic deposits on the spatial distribution of bacterial communities is reinforced. Considering only the operating cycle, a greater number of gene copies were found during the feeding period, from which we can infer a greater functional potential of these bacteria in this period. System S4 also presented a higher number of gene copies /g pellet for AOB and total bacteria at the $30 \mathrm{~cm}$ depth, however with higher values in the rest period. These results may be related to the oxygen content at the surface during rest and the transfer of nutrients to deeper layers during feeding impacting bacterial metabolism.

\subsubsection{6s rRNA sequencing of the dynamics of microbial community}

To explore the microbial community structure and identify the main genera present in VF wetlands, we used a more exhaustive analysis based on High-throughput $16 \mathrm{~S}$ rRNA sequencing. This technique is highly effective in assessing shifts in microbial communities and consequently, in understanding microbial dynamics over space and time [9]. Besides, if the enzymatic/functional capabilities of a microbial community are considered, one could generate an idea of potential function [8]. For this reason, PICRUSt was applied to understand the potential of microbial function linked to the nitrogen cycle.
A total of 640,663 sequences were retrieved from 15 samples from all four full-scale systems by the Highthroughput $16 \mathrm{~S}$ rRNA Illumina MiSeq ${ }^{\mathrm{TM}}$ sequencing platform. After quality control by mothur and chimera to remove low quality reads (Phred <24), a total of 258,590 high-quality sequences remained for further analysis.

Chao1 was use used to estimate richness in a sample and is based upon the number of rare classes (i.e. OTUs observed). Among the samples evaluated, the effluent sample S2_D0 showed the highest estimated richness (224.20), and the sample containing the lowest richness was S3_D15_r (119.55). The same was observed for the number of bacterial OTUs (Supplementary Table 1). The microbial community richness illustrated the remarkable spatial variation in each French VF wetland system; however, the highest values were found in systems with longer operating time (LOT), specifically in the summer with decreasing in depth. This pattern of behavior can be observed in Supplementary Figure 2, which shows the result of the Alpha Diversity indices.

Rarefaction analysis (Supplementary Figure 3) was employed to evaluate the sample coverages. All samples showed asymptotic curves, indicating that the sampling effort was sufficient to cover the overall richness. These results are similar to the Good's coverage values ( $>0.98$ ), reinforcing that the samples were sequenced at a high depth. 


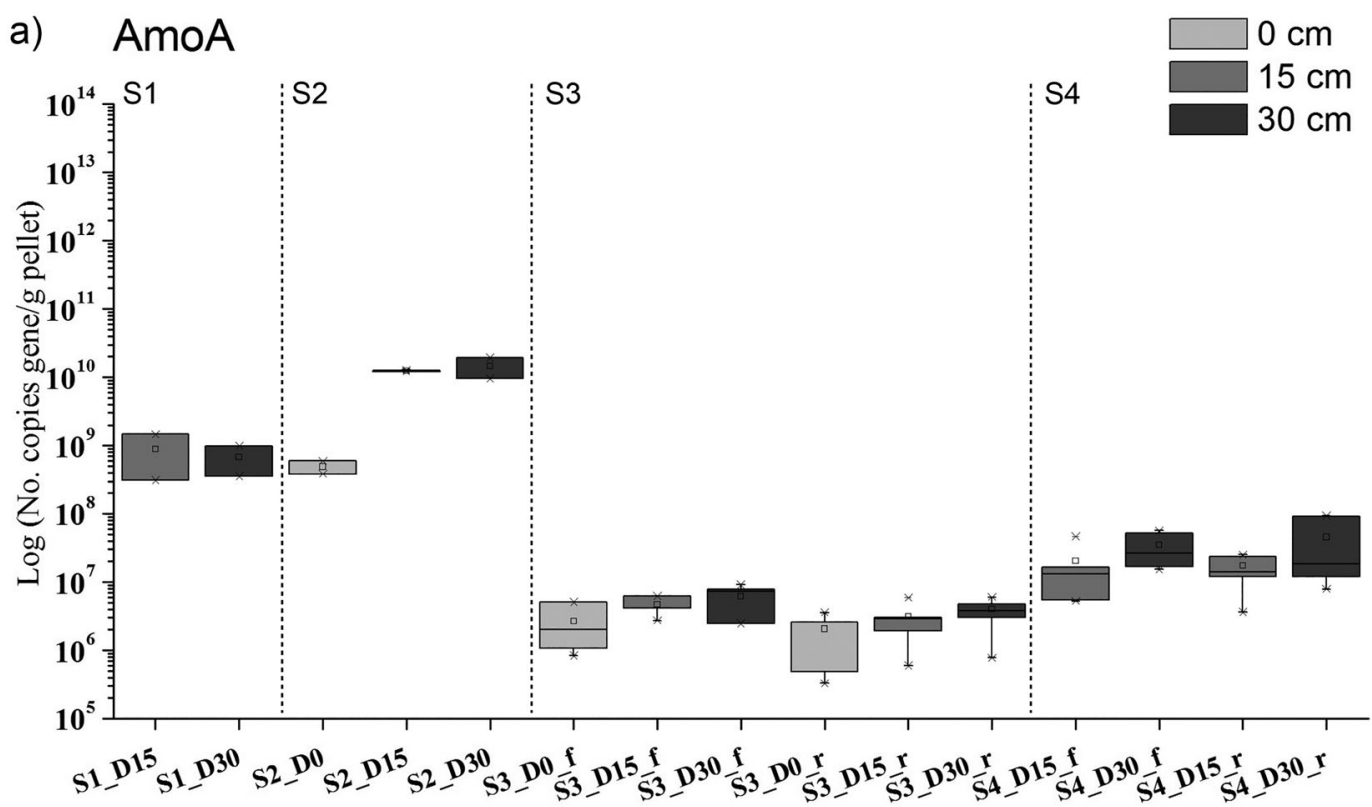

French VF wetlands: S1, S2, S3 and S4

b) Total bacteria

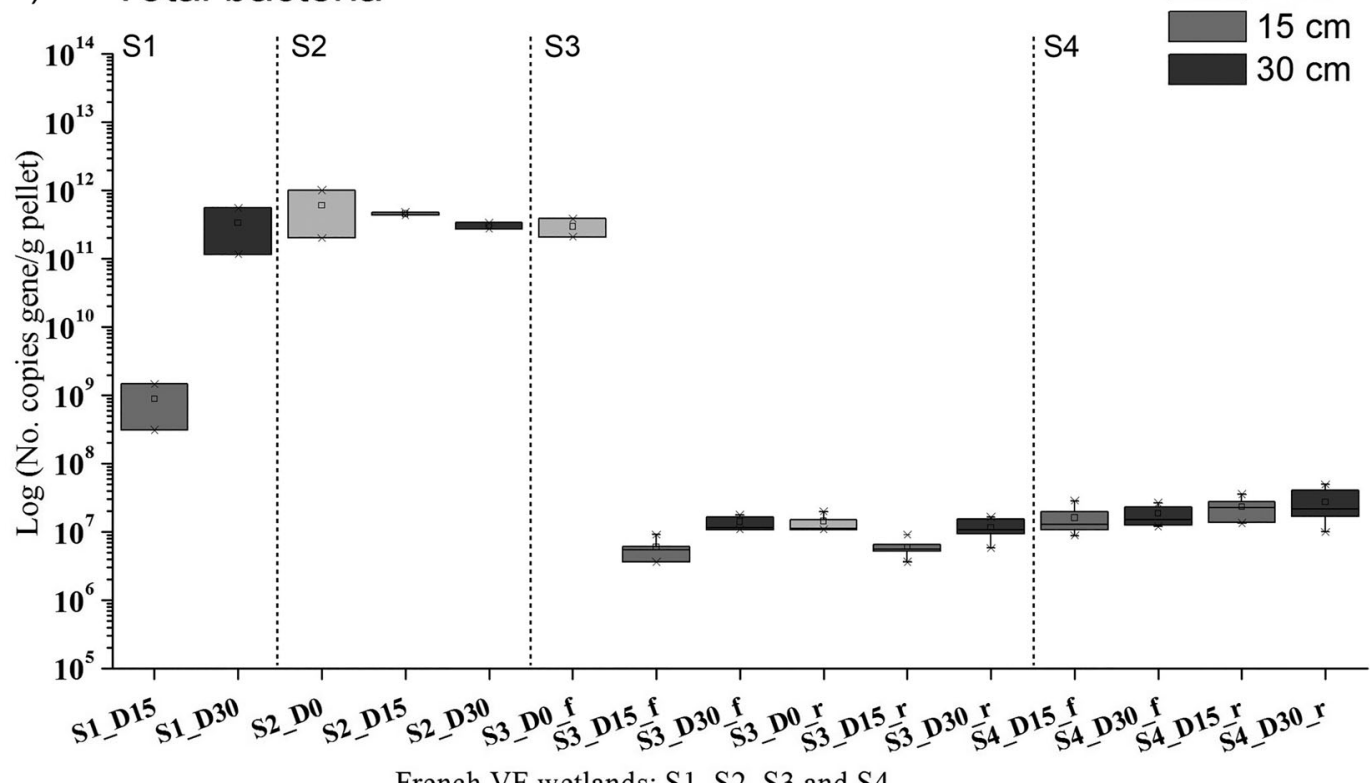

French VF wetlands: S1, S2, S3 and S4

Figure 5. qPCR of the tested French vertical flow wetlands (S1; S2; S3; and S4). Absolute values. (a) Nitrifying bacteria (amoA, primers $1 \mathrm{~F}$, and $2 \mathrm{R}$ ) and (b) Total bacteria (primers $1055 \mathrm{~F}$ and 1392R).

According to the Shannon index, the microbial diversity also varied significantly, probably due to the specific factors of each system evaluated, such as operating time, operating cycle, temperature, and oxygenation. However, the highest Shannon index (3.79) was observed for a LOT system (S2_D0) sampled in winter during the rest period. This result can indicate that despite the presence of snow in the mountain station, little change in the microbial diversity was observed in this system. Interestingly, the sample that showed the lowest Shannon index (3.10) comes from the same system at $30 \mathrm{~cm}$ (Supplementary Table 1). This result coincides with the visually observed results for the DGGE, where greater diversity was seen in the first depth layers, in the summer, and in the deeper layer prevailed the nitrifying bacteria.

Principal coordinates analysis (PCoA), based on the Bray-Curtis distance metric, and was applied to evaluate 


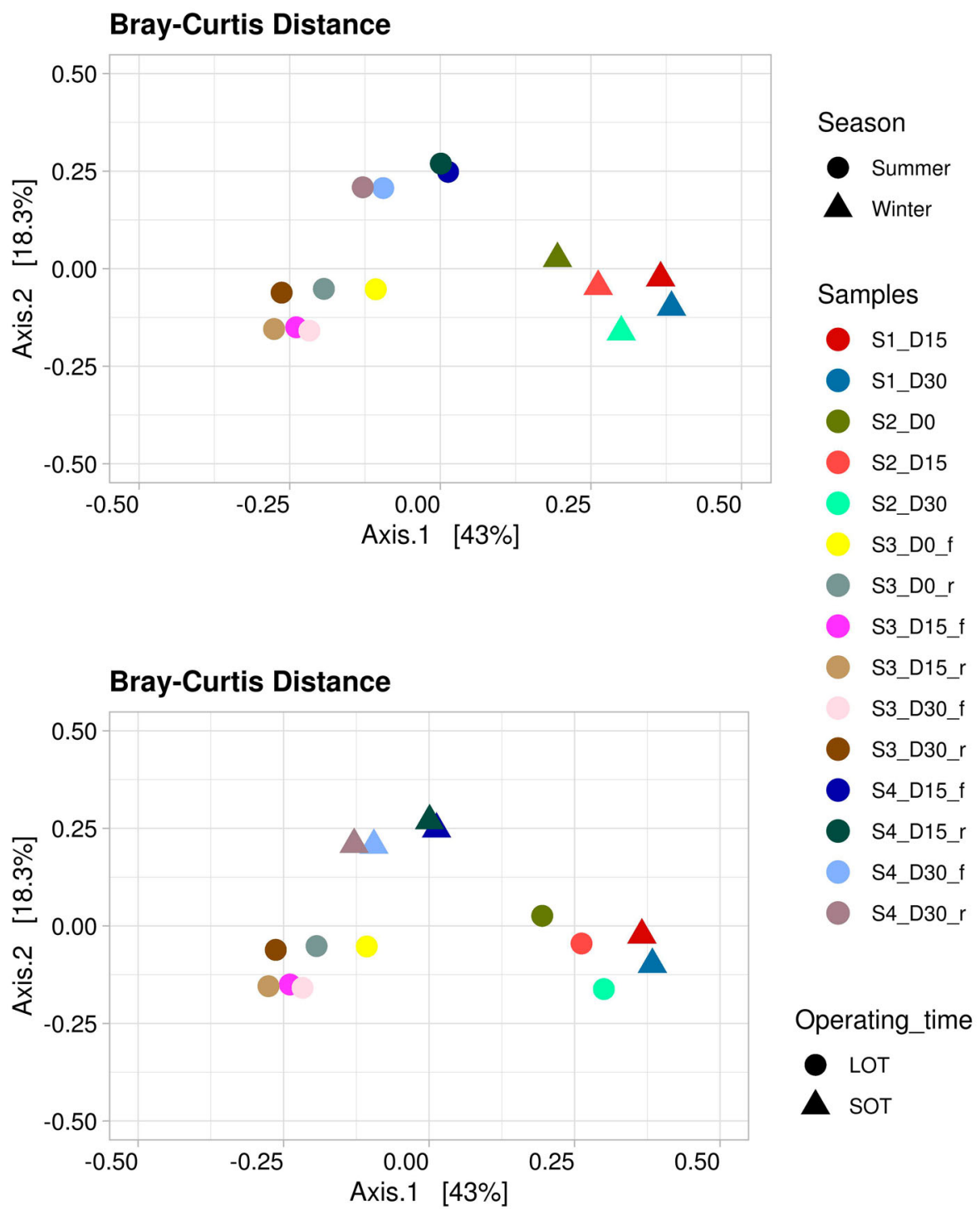

Figure 6. Principal coordinate analysis (PCoA) plot using Bray-Curtis distances.

the patterns of similarities of the samples and how the samples group according to metadata information (Figure 6). The results of PCoA corroborated the results of other analyses performed in this study. The samples showed a pattern of distribution according to the season of the year in which they were collected - the systems S3 and S4 in the summer and systems S1 and S2 in the winter (Figure 6a). A subdivision within the samples collected in summer and winter was observed about the variable LOT and SOT systems (Figure 6b). Other metadata information was tested, but the pattern of distribution was not conclusive. In this way, the PCoA results indicate that the variables, operating time and measurement season, were responsible for the similarity pattern of the samples and, consequently, microbial community behavior present in the systems.
3.2.3.1. Taxonomies and functional prediction. Sequences derived from all samples were distributed among 12 distinct phyla (Supplementary Figure 4). The most abundant phyla in all samples were Proteobacteria, Bacteroidetes, Actinobacteria, Nitrospirae, Chloroflexi, Acidobacteria, and Gemmatimonadetes. A higher relative abundance of all the phyla identified in the summer was clearly observed. However, concerning the other variables analyzed, no pattern was found, and the dynamics of these phyla seemed to be more related to their characteristics.

At the genus level, Mycobacterium, Acinetobacter, Flavobacterium, and Rhodanobacter were the most abundant genera in S1 and S2 systems (SOT and LOT, respectively, in the winter) (Figure 7). In the samples collected in the summer period (S3 and S4), two of the most 


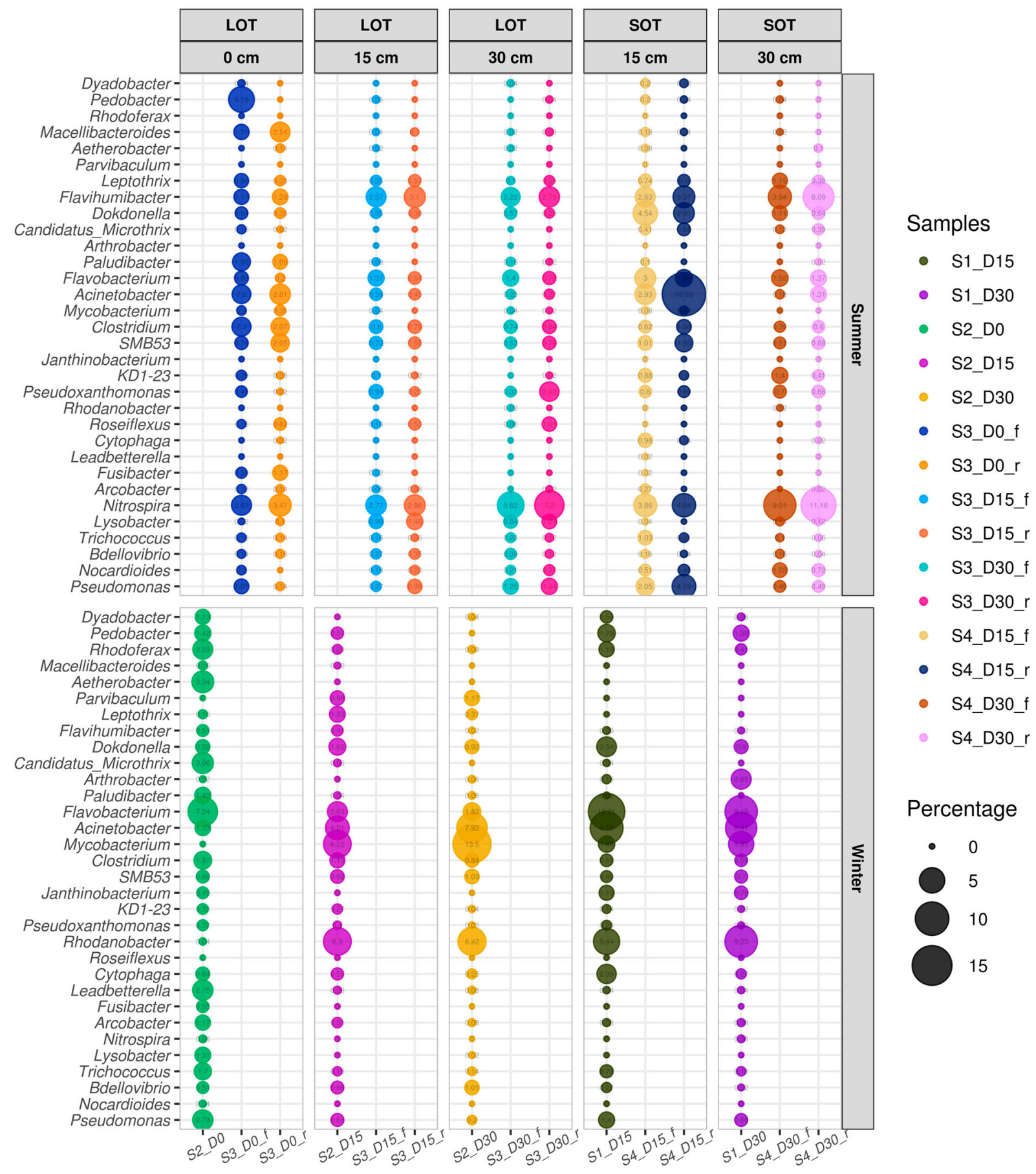

Figure 7. Relative abundance at the genus level found in the datasets of the French VF wetland.

abundant genera highlighted, Flavihumibacter and Nitrospira.

The Mycobacterium genus is a strict aerobic organism and gram-positive, associated with carbon degradation and can support nitrification; species that promote heterotrophic nitrification produce $\mathrm{NO}_{3}^{-} \mathrm{N}[43,44]$. An exponential increase in the relative abundance concerning depth was observed, with higher values at $30 \mathrm{~cm}$ (Figure 7). This result may be related to the presence of aeration drains located at the bottom of the filter. In winter, aeration from the bottom is essential since the deposit layer can stay saturated for several days. Finally, temperature was the variable that affected the community structure of this genus since for the S3 and S4 systems (in the summer) the genus had no significant presence. The same was observed for the Rhodanobacter genus. The same was observed for the Rhodanobacter genus. This genus is considered a denitrifying bacterium, beyond, Cytophaga, Pseudomonas, Dokdonella and Pedobacter also appeared, although with a lower relative abundance. 
Regarding Flavobacterium, in contrast to Mycobacterium, a decrease in relative abundance with depth for all systems was observed (except in system S3, with higher value in $15 \mathrm{~cm}$ ). It can also be noted that the values were higher in the period of feeding than in the period of rest. This behavior can be justified due to its characteristics. Members of this group are autochthonous soil bacteria [45] and are closely linked with the biodegradation of a variety of organic pollutants and nitrification $[23,46]$. Some studies have reported that this genus is associated with aerobic denitrification and helps to shorten the duration required for this process, thus providing a new route for denitrification [47]; furthermore, it has been well detected in vertical flow systems [10] and at low temperatures, such as $10{ }^{\circ} \mathrm{C}$ [45]. Additioanlly, Acinetobacter has also recently been cited as able to perform the heterotrophic nitrification and aerobic denitrification [48]. Compared to the others, it was found with a significant abundance in all winter samples, although the highest relative abundance was in the sample S4_D15_r (16.7\%).

As shown in Figure 7, the genus that stood out in systems S3 and S4 (analyzed in summer) was Nitrospira. This genus notably increased with depth and the highest relative abundance was found at $30 \mathrm{~cm}$ during the rest period. The sample that obtained the highest percentage value was D30_f (8.8\%) and D30_r (10.8\%). The predominance of this genus in the rest period (period with small substrate concentrations) may be associated with some survival strategies, such as their low Ks. This makes them K-strategic bacteria, which means that they are well adapted to low concentrations of nitrite and oxygen. It was also reported by other studies $[49,50]$ that states that the genus Nitrospira can increase under these conditions. Concerning the depth, the fact that there was a greater abundance at a $30 \mathrm{~cm}$ may be linked to several factors, such as the presence of aeration drains at the bottom of the filter that, coupled with the coarse drainage layer, promote good aeration from the bottom.

The genus Nitrospira comprises facultative autotrophic chemolithotrophic organisms and is composed of gram-negative bacteria. This genus is one of the most diverse known nitrifier groups and colonizes all oxic ecosystems, including high-temperature environments. For over a century, this genus has been described as responsible for the second step of nitrification (nitrites to nitrates) [51]. However, a remarkable study [52] reported the capacity of a bacterium from the genus Nitrospira to catalyze complete nitrification. The authors noted that a complete nitrifier ('comammox,' complete ammonia oxidizer) might be competitive under conditions that favor the maximization of growth yield rather than growth rate but still reported that metagenomic studies had revealed the dominance of Nitrospira over AOB. Another study [17] also reported the predominance of Nitrospira over $A O B$, possibly suggesting the presence of the comammox process. This may be able to partially explain the behavior of this genus in our study.

Concerning the nitrification process and the variable seasonality, the results of High-throughput sequencing, as well as the results obtained by $\mathrm{gPCR}$ and DGGE, showed the influence of temperature on the microbial community structure of both nitrifying bacteria and total bacteria. The increase in the genus Nitrospira in the systems evaluated in the summer period (S3 and S4) indicates an increase nitrification rate, which is sought in such aerobic systems. However, even at lower temperatures, the filters analyzed in this study had good nitrification efficiency. From this, we can suggest that depending on other factors that interfere with the system and that help to maintain bacterial metabolism, good nitrogen removal can also occur in winter. Some studies observed no difference in removal rates in treatment wetlands between summer and winter $[53,54,55]$. This trend has also been observed in French VF wetlands in cold climates [3].

Finally, results from PICRUSt highlights the functional dynamics of genes associated with nitrogen conversion, including nitrification, denitrification, and dissimilatory and assimilatory nitrate reduction (Figure 8).

Regarding the genes of the nitrogenase complex responsible for the conversion of atmospheric nitrogen $\left(\mathrm{N}_{2}\right)$ to other forms of nitrogen such as ammonia - nifK, nifH, and nifD - a higher percentage was observed in the summer period without a significant difference to depth. Looking at the genes related to the metabolism of $A O B$ (hao, hydroxylamine oxidoreductase), a low prediction in all analyzed samples was found. The other techniques used in this study also showed a lower relative abundance of $A O B$ compared to other bacterial groups.

Nitric oxide reductase genes related to denitrification as the nor $B$ and nor $C$ showed higher predicted abundances in winter samples, with the nor $B$ gene being more expressed than norC. No difference was observed in their predictions for the other variables. Other genes linked to denitrification such as nitrate reductase, nor $A$, narL, narH, narG, nirk, and nosZ (nitrous oxide reductase) [56] were observed. Due to the good efficiency of the nitrification documented in the evaluated systems, we can infer that the significant presence of denitrifying genes in vertical systems is related to the conditions of each system and temperature. The well-established sludge layer on the surface of the filters and feeding 

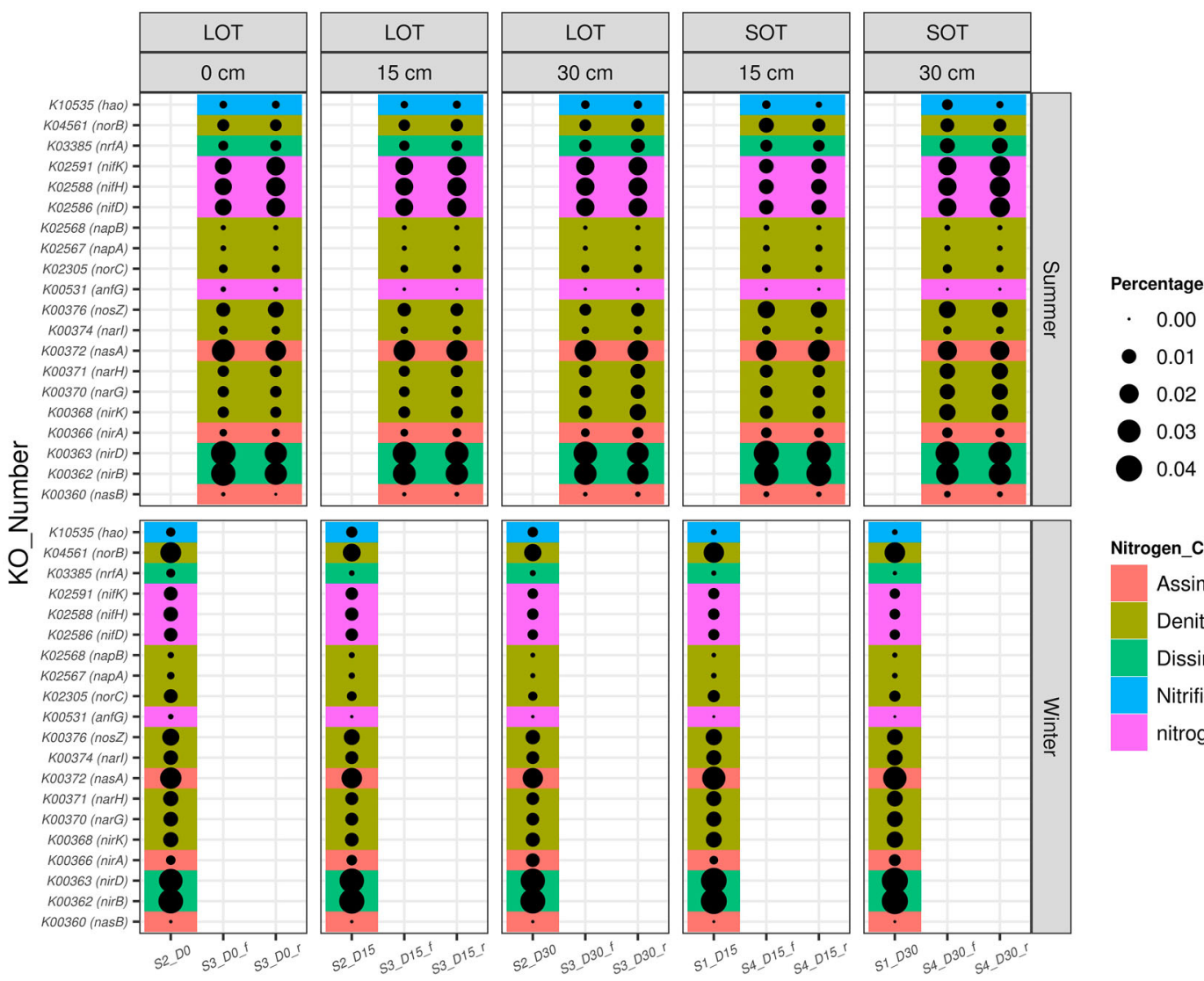

Figure 8. Functional genes involved in biological nitrogen cycling found in the datasets of the French VF wetland as predicted by PICRUSt.

periods, where the oxygen decreases, may also have contributed to this result.

Functions associated with nitrite reductase were evidenced by the genes nrfA, nirD, and nirB. The results indicated a high presence of these genes in comparison to the others under any condition the dissimilatory process (nitrate $\rightarrow$ ammonia) was observed.

The results of functional prediction still showed genes related to the assimilatory process of nitrate, mainly enzymes for rhizobial denitrification. The nas $A$ gene is considered to be a $\mathrm{NO}_{3}^{-} / \mathrm{NO}_{2}^{-}$transporter, i.e. required for the assimilatory $\mathrm{NO}_{3}^{-} / \mathrm{NO}_{2}^{-}$reductase apparatus and $\mathrm{NO}_{2}^{-}$reductase (nasB). Both had a very similar percentage in all the samples evaluated, with smaller values for the $n a s B$ gene. In addition, the nirA gene (assimilatory nitrite reductase) was found, with the highest percentage in winter samples and a slight increase at $30 \mathrm{~cm}$ depth. This genus is considered Key for $\mathrm{NO}_{3}^{-}$assimilation and is immediately downstream of genes recently reported to code for a $\mathrm{NO}_{3}^{-} / \mathrm{NO}_{2}^{-}$responsive regulatory system (asS-NasT) [56].

In summary, it seems that the behavior microbial community from the functional prediction was more affected by temperature. Another important point to note is that even if the systems have a vertical flow prioritizing nitrification the taxonomies and predicted genes for the denitrification process were found. This factor allowed us to further understand the bacterial dynamics and to be able to advance the idea that modifications made in the first stage of the classical French system to improve nitrogen removal are promising. In this sense, the importance of this study was reinforced. As an example, the use of the saturated bottom layer in the first stage (French VF wetlands) [57] promoted the total simultaneous treatment of nitrogen in the same filter, thereby reducing the required area and operating costs of the treatment. This modification would have create a different microbial community profile to achieve these results.

\section{Conclusions}

Based on the results of the molecular analyses of the microbiological communities of four classical French vertical flow wetlands treating domestic wastewater at a full-scale. The main conclusions are as follows: 
- The sludge layer significantly interferes in the filter operation, not only in a hydraulic sense but also in the microbial community providing food for the bacteria that perform nitrification and denitrification throughout the verticality of the filter.

- Greater diversity was seen in the first depth layers, and in the deeper layer prevailed the nitrifying bacteria. Regardless of the presence of snow in the mountain station, little change in the bacterial diversity was observed. This result could be indicated that even in winter, good nitrification efficiency can be achieved with a well-established community.

- An apparent decline in the diversity was observed throughout the cycle of operation; thus, the classical 7-day rest period was reinforced.

- $\mathrm{qPCR}$ indicated that the largest amount of $A O B$ was found at $30 \mathrm{~cm}$ depth. Concerning the operating cycle, a greater number of copies were found during the feeding period, from which we can infer a greater functional potential of these bacteria in this period.

- Mycobacterium, Acinetobacter, Flavobacterium, Rhodanobacter, Flavihumibacter, and Nitrospira were the abundant genera highlighted. Nitrospira stood out in the summer, at $30 \mathrm{~cm}$ depth with a slight increase in the resting period and overcame AOB.

- The presence of denitrifying genes in vertical systems is related to the conditions of each system and temperature, with a more significant presence in the winter, as expected. However, they were detected to the depth of $30 \mathrm{~cm}$.

- Integrated analysis of the results revealed that the variables, time of operation (presence/absence of sludge layer) and temperature, were responsible for the distribution pattern of the samples based on taxonomic profile and, consequently, for the behavior of the microbial community present in the systems.

\section{Acknowledgements}

The authors would like to thank the French Institute IRSTEA for providing the possibility of studying these systems and allowing us to perform the analyses. This work was supported by the AFB (French Agency for biodiversity); the CAPES (Coordenação de Aperfeiçoamento de Pessoal de Nível Superior), Brazil, under Grant (Finance Code 001) and the TSGA (Social Technologies for Water Management) project (Finance Petrobras - Petrobras Socio-Environmental Program -Brazil).

\section{Disclosure statement}

No potential conflict of interest was reported by the author(s).

\section{Funding}

This work was supported by Coordenação de Aperfeiçoamento de Pessoal de Nível Superior: [Grant Number 001].

\section{ORCID}

D.D. Silveira (D) http://orcid.org/0000-0002-8299-0030

T.P. Delforno (D) http://orcid.org/0000-0002-1705-0763

\section{References}

[1] Molle $P$, Liénard $A$, Boutin $C$, et al. How to treat raw sewage with constructed wetlands: An overview of the French systems. Wat Sci \& Tech. 2005;51(9):11-21. doi:10.2166/wst.2005.0277.

[2] Molle P. French vertical flow constructed wetlands: a need of a better understanding of the role of the deposit layer. Water Sci Technol. 2014;69(1):106-112. doi:10.2166/wst. 2013.561.

[3] Prost-Boucle S, Garcia O, Molle P. French vertical-flow constructed wetlands in mountain areas: How do cold temperatures impact performances? Water Sci Technol. 2015;71(8):1219-1228. doi:10.2166/wst.2015.074.

[4] Masi F, Bresciani R, Martinuzzi N, et al. (2016). Large scale application of French Reed Beds: municipal wastewater treatment for a 20,000 inhabitant's town in Moldova. In 15th IWA International Conference on Wetland Systems for Water Pollution Control - 4-9 September, 2016, Gdańsk, Poland. doi:10.2166/wst.2017.188.

[5] Molle P, Lombard Latune R, Riegel C, et al. French verticalflow constructed wetland design: Adaptations for tropical climates. Water Sci Technol. 2015;71(10):1516-1523. doi:10.2166/wst.2015.133.

[6] Manjate ES, Lana LC, Moraes DC, et al. First stage of the French vertical flow constructed wetland system: Experiments with the reduction of surface area and number of units. J Wat Sanit Hyg Devel. 2015;5(1):50-55. doi:10.2166/washdev.2014.009.

[7] Lombard-Latune R, Pelus L, Fina N, et al. Resilience and reliability of compact vertical-flow treatment wetlands designed for tropical climates. Sci Total Environ 2018;642:208-215. doi:10.1016/j.scitotenv.2018.06.036.

[8] Weber K. Microbial community assessment in wetlands for water pollution control: Past, present, and future outlook. Water (Basel). 2016;8(11):503. doi:10.3390/w8110503.

[9] Shin NR, Whon TW, Bae JW. Proteobacteria: microbial signature of dysbiosis in gut microbiota. Trends Biotechnol. 2015;33(9):496-503. doi:10.1016/j.tibtech.2015.06.011.

[10] Adrados B, Sánchez O, Arias CA, et al. Microbial communities from different types of natural wastewater treatment systems: vertical and horizontal flow constructed wetlands and biofilters. Water Res. 2014;55:304-312. doi:10.1016/j.watres.2014.02.011.

[11] Ansola G, Arroyo P, de Miera LES. Characterization of the soil bacterial community structure and composition of natural and constructed wetlands. Sci Total Environ. 2014;473-474:63-71. doi:10.1016/j.scitotenv.2013.11.125.

[12] Button M, Weber K, Nivala J, et al. Community-level physiological profiling of microbial communities in constructed wetlands: effects of sample preparation. Appl Biochem Biotechnol. 2016;178(5):960-973. doi:10.1007/ s12010-015-1921-7.

[13] Babatunde AO, Miranda-CasoLuengo R, Imtiaz M, et al. Performance assessment and microbial diversity of two pilot scale multi-stage sub-surface flow constructed 
wetland systems. J Environ Sci. 2016;46:38-46. doi:10. 1016/j.jes.2015.02.018.

[14] Bai Y, Sun Q, Wen D, et al. Abundance of ammonia-oxidizing bacteria and archaea in industrial and domestic wastewater treatment systems. FEMS Microbiol Ecol. 2012;80 (2):323-330. doi:10.1111/j.1574-6941.2012.01296.x.

[15] Pelissari C, Ávila C, Trein CM, et al. Nitrogen transforming bacteria within a full-scale partially saturated vertical subsurface flow constructed wetland treating urban wastewater. Sci Total Environ. 2017;574:390-399. doi:10.1016/j. scitotenv.2016.08.207.

[16] Zhang M, Luo P, Liu F, et al. Nitrogen removal and distribution of ammonia-oxidizing and denitrifying genes in an integrated constructed wetland for swine wastewater treatment. Ecol Eng. 2017;104:30-38. doi:10.1016/j. ecoleng.2017.04.022.

[17] Pelissari C, Guivernau M, Viñas M, et al. Effects of partially saturated conditions on the metabolically active microbiome and on nitrogen removal in vertical subsurface flow constructed wetlands. Water Res. 2018;141:185195. doi:10.1016/j.watres.2018.05.002.

[18] Chen Y, Wen Y, Tang Z, et al. Effects of plant biomass on bacterial community structure in constructed wetlands used for tertiary wastewater treatment. Ecol Eng. 2015;84:38-45. doi:10.1016/j.ecoleng.2015.07.013.

[19] Lv T, Carvalho PN, Zhang L, et al. Functionality of microbial communities in constructed wetlands used for pesticide remediation: influence of system design and sampling strategy. Water Res. 2017;110:241-251. doi:10.1016/j. watres.2016.12.021.

[20] Luo Z, Li S, Zhu X, et al. Carbon source effects on nitrogen transformation processes and the quantitative molecular mechanism in long-term flooded constructed wetlands. Ecol Eng. 2018;123:19-29. doi:10.1016/j.ecoleng.2018.08. 011.

[21] López D, Sepúlveda-Mardones M, Ruiz-Tagle N, et al. Potential methane production and molecular characterization of bacterial and archaeal communities in a horizontal subsurface flow constructed wetland under cold and warm seasons. Sci Total Environ. 2019;648:1042-1051. doi:10.1016/j.scitotenv.2018.08.186.

[22] Truu M, Juhanson J, Truu J. Microbial biomass, activity and community composition in constructed wetlands. Sci Total Environ. 2009;407(13):3958-3971. doi:10.1016/j. scitotenv.2008.11.036.

[23] Guan W, Yin M, He T, et al. Influence of substrate type on microbial community structure in vertical-flow constructed wetland treating polluted river water. Env Sci Pollut Res. 2015;22(20):16202-16209. doi:10.1007/ s11356-015-5160-9.

[24] Cydzik-Kwiatkowska A, Zielińska M. Bacterial communities in full-scale wastewater treatment systems. World J Microbiol Biotechnol. 2016;32(4):66. doi:10.1007/s11274016-2012-9.

[25] Bouali M, Zrafi I, Bakhrouf A, et al. Bacterial structure and spatiotemporal distribution in a horizontal subsurface flow constructed wetland. Appl Microbiol Biotechnol. 2014;98:3191-3203. doi:10.1007/s00253-013-5341-8.

[26] lasur-Kruh L, Hadar Y, Milstein D, et al. Microbial population and activity in wetland microcosms constructed for improving treated municipal wastewater. Microb Ecol. 2010;59:700-709. doi:10.1007/s00248-009-9611-z.
[27] Chang JJ, Wu SQ, Liang K, et al. Comparative study of microbial community structure in integrated verticalflow constructed wetlands for treatment of domestic and nitrified wastewaters. Environ Sci Pollut Res. 2015;22:3518-3527. doi:10.1007/s11356-014-3594-0.

[28] Arroyo P, Ansola G, de Miera LES. Effects of substrate, vegetation and flow on arsenic and zinc removal efficiency and microbial diversity in constructed wetlands. Ecol Eng. 2013;51:95-103. doi:10.1016/j.ecoleng.2012.12.013.

[29] Morvannou A, Forquet N, Michel S, et al. Treatment performances of French constructed wetlands: results from a database collected over the last 30 years. Water Sci Technol. 2015;71(9):1333-1339. doi:10.2166/wst.2015.089.

[30] Dotro G, Langergraber G, Molle P, et al. Treatment wetlands (Vol. 7). London: IWA publishing; 2017; ISBN: 9781780408767.

[31] Kowalchuk GA, Stephen JR, De Boer WIETSE, et al. Analysis of ammonia-oxidizing bacteria of the beta subdivision of the class Proteobacteria in coastal sand dunes by denaturing gradient gel electrophoresis and sequencing of PCRamplified 16S ribosomal DNA fragments. Appl Environ Microbiol. 1997;63(4):1489-1497.

[32] Rotthauwe JH, Witzel KP, Liesack W. The ammonia monooxygenase structural gene amoA as a functional marker: molecular fine-scale analysis of natural ammonia-oxidizing populations. Appl Environ Microbiol. 1997;63 (12):4704-4712.

[33] Lane DJ. 16S/23S rRNA sequencing. In: Stackebrandt EGM, editor. Nucleic acid techniques in bacterial systematics. Cambridge: John Wiley and Sons Ltd; 1991. p. 115-175.

[34] Ferris MJ, Muyzer G, Ward DM. Denaturing gradient gel electrophoresis profiles of $16 \mathrm{~S}$ rRNA-defined populations inhabiting a hot spring microbial mat community. Appl Environ Microbiol. 1996;62:340-346.

[35] Wang Y, Qian PY. Conservative fragments in bacterial 16S rRNA genes and primer design for 16S ribosomal DNA amplicons in metagenomic studies. PloS one. 2009;4(10): e7401. doi:10.1371/journal.pone.0007401.

[36] Caporaso JG, Lauber CL, Walters WA, et al. Global patterns of $16 \mathrm{~S}$ rRNA diversity at a depth of millions of sequences per sample. Proc Natl Acad Sci U S A. 2011;108 (Supplement 1):4516-4522. doi:10.1073/pnas.10000801 07.

[37] Takahashi S, Tomita J, Nishioka K, et al. Development of a prokaryotic universal primer for simultaneous analysis of bacteria and archaea using next-generation sequencing. PloS one. 2014;9(8):e105592. doi:10.1371/journal.pone. 0105592.

[38] Schloss PD, Westcott SL, Ryabin T, et al. Introducing mothur: open-source, platform-independent, community-supported software for describing and comparing microbial communities. Appl Environ Microbiol. 2009;75 (23):7537-7541. doi:10.1128/AEM.01541-09.

[39] Kozich JJ, Westcott SL, Baxter NT, et al. Development of a dual-index sequencing strategy and curation pipeline for analyzing amplicon sequence data on the MiSeq Illumina sequencing platform. Appl Environ Microbiol. 2013;79 (17):5112-5120. doi:10.1128/AEM.01043-13.

[40] Quast C, Pruesse E, Yilmaz P, et al. The SILVA ribosomal RNA gene database project: improved data processing and web-based tools. Nucleic Acids Res. 2012;41(D1): D590-D596. doi:10.1093/nar/gks1219. 
[41] Langille MG, Zaneveld J, Caporaso JG, et al. Predictive functional profiling of microbial communities using $16 \mathrm{~S}$ rRNA marker gene sequences. Nat Biotechnol. 2013;31 (9):814-821.

[42] Caporaso JG, et al. QIIME allows analysis of high-throughput community sequencing data. Nat Methods. 2010; doi:10.1038/nmeth.f.303.

[43] Saeed T, Sun G. A review on nitrogen and organics removal mechanisms in subsurface flow constructed wetlands: dependency on environmental parameters, operating conditions and supporting media. J Environ Manage. 2012;112:429-448. doi:10.1016/j.jenvman.2012.08.011.

[44] Ventura M, Canchaya C, Tauch A, et al. Genomics of Actinobacteria: tracing the evolutionary history of an ancient phylum. Microbiol Mol Biol Rev. 2007;71(3):495548. doi:10.1128/MMBR.00005-07.

[45] Zhao X, Yang J, Bai S, et al. Microbial population dynamics in response to bioaugmentation in a constructed wetland system under 10 C. Bioresour Technol. 2016;205:166-173. doi:10.1016/j.biortech.2016.01.043.

[46] Yuan J, Dong W, Sun F, et al. Bacterial communities and enzymatic activities in the vegetation-activated sludge process (V-ASP) and related advantages by comparison with conventional constructed wetland. Bioresour Technol. 2016;220:341-351. doi:10.1016/j.biortech.2016.08.095.

[47] Fu G, Yu T, Huangshen $L$, et al. The influence of complex fermentation broth on denitrification of saline sewage in constructed wetlands by heterotrophic nitrifying/aerobic denitrifying bacterial communities. Bioresour Technol. 2018;250:290-298. doi:10.1016/j.biortech.2017.11.057.

[48] Chen S, He S, Wu C, et al. Characteristics of heterotrophic nitrification and aerobic denitrification bacterium Acinetobacter sp. T1 and its application for pig farm wastewater treatment. J Biosci Bioeng. 2019;127(2):201-205.

[49] Pelissari C, dos Santos MO, Rousso BZ, et al. Organic load and hydraulic regime influence over the bacterial community responsible for the nitrogen cycling in bed media of vertical subsurface flow constructed wetland. Ecol Eng. 2016;95:180-188. doi:10.1016/j.ecoleng.2016.06.079.

[50] Nogueira R, Melo LF. Competition between Nitrospira spp. and Nitrobacter spp. in nitrite-oxidizing bioreactors. Biotechnol Bioeng. 2006;95(1):169-175. doi:10.1002/bit. 21004.

[51] Ge S, Wang S, Yang X, et al. Detection of nitrifiers and evaluation of partial nitrification for wastewater treatment: a review. Chemosphere. 2015;140:85-98. doi:10. 1016/j.chemosphere.2015.02.

[52] Daims H, Lebedeva EV, Pjevac P, et al. Complete nitrification by Nitrospira bacteria. Nature. 2015;528(7583):504509. doi:10.1038/nature16461.

[53] Cookson WR, Cornforth IS, Rowarth JS. Winter soil temperature (2-15 C) effects on nitrogen transformations in clover green manure amended or unamended soils; a laboratory and field study. Soil Biol Biochem. 2002;34 (10):1401-1415.

[54] Sundberg C, Stendahl JS, Tonderski K, et al. Overland flow systems for treatment of landfill leachates-potential nitrification and structure of the ammonia-oxidising bacterial community during a growing season. Soil Biol Biochem. 2007;39(1):127-138. doi:10.1016/j.soilbio.2006. 06.016.

[55] Nivala J, Hoos MB, Cross C, et al. Treatment of landfill leachate using an aerated, horizontal subsurface-flow constructed wetland. Sci Total Environ. 2007;380(1-3):19-27. doi:10.1016/j.scitotenv.2006.12.030.

[56] Cabrera JJ, Salas A, Torres MJ, et al. An integrated biochemical system for nitrate assimilation and nitric oxide detoxification in Bradyrhizobium japonicum. Biochem J. 2016;473(3):297-309.

[57] Silveira DD, Belli Filho P, Philippi LS, et al. Influence of partial saturation on total nitrogen removal in a singlestage French constructed wetland treating raw domestic wastewater. Ecol Eng. 2015;77:257-264. doi:10.1016/j. ecoleng.2015.01.040. 